Serological follow-up after rubella immunisation

SIR,-We fully support the comment of Mr P Curzen (16 July, p 186). Rubella vaccination alone without serological follow-up 10 weeks later is unsatisfactory but is being used for the immunisation of adolescents for economic reasons. Many countries have adopted this policy. In case of a later pregnancy and simultaneous contact with a case of rubella the measures to be taken are clear, if haemagglutination-inhibiting (HI) antibodies are lacking.

A woman who had had no serological tests for three years after rubella vaccination was in the third month of pregnancy when her son and husband developed rubella. Her rubella $(\mathrm{HI})$ titre at this time was $1 / 40$. The doctor immediately gave rubella hyperimmune serum and 21 days later the titre had risen to $1 / 160$. Fortunately no $\operatorname{IgM}$ antibodies were found in the second specimen. Therefore a booster reaction due to rubella contact or possibly due to the passive immunisation was assumed. This example explains why many doctors will have an unpleasant feeling in such a situation without serological data. This is the reason why we favour selective rubella vaccination of seronegative persons at 15 years of age with later follow-up of $\mathrm{HI}$ antibodies.

W EHRENGUT H LENNARTZ

Hamburg, W Germany

\section{Infantile acne}

SIR,-The skin condition described by Dr D Rowley-Jones (23 July, p 266) in both his children sounds like milia, which many call "milk spots." It is probably hormonal in origin, though this has not yet been proved. It is quite common and is described in many textbooks. The eruption is mainly on the face and appears very shortly after birth. No treatment is needed and it always clears up completely before the child is three months old. There is neither a greater nor a lesser risk of these children getting eczema (which rarely appears before six weeks).

London W12

StUART CARNE

\section{Accident or suicide?}

SIR,-In your leading article (23 July, p 212) on this subject you conclude that "accidental deaths-especially those due to self-poisoning, solitary drowning, and falls from a heightshould be included in the mortality of mental illness." Such an opinion supports the consensus view that suicide is, by definition, always evidence of mental derangement. Is it not time to challenge this axiomatic position and to recognise the perfect normality of thinking of some at least who decide to die by act of will? There are examples, not by any means rare, where the verdict "suicide while the balance of mind was disturbed" is patently false, as, for instance, in terminal conditions associated with prolonged suffering.

To insist as we do today that all natural dying must, by definition, be involuntary is to perpetuate a myth, necessary at one time for social cohesion but untenable in the light of contemporary thinking. Why should "voluntary dying" not become acceptable as a statistical category in an age which prides itself on its enlightenment and reason?

Huddersfield

$S$ L HENDERSON SMITH

\section{Industrial action}

SIR,-I strongly reject the proposed "oneday strike" for doctors. It harms the longsuffering patients and does no harm to those who control the purse. It may even benefit them, using their warped costing systems. If we do have a one-day strike and it has no effect (which will almost certainly be the case) we will by this gesture (1) produce a loss of credibility and a loss of sympathy with the general public and (2) give the "strong-arm unions" a perfect excuse for using our example as a support for their huge demands. If we win a second pay award within a few months of our last one (albeit as yet unpaid) we will open the gates for demands every two or three months from every work and non-work group in the country.

It seems that our Review Body is not an independent body and we should probably not waste time listening to their two-faced decisions. If they deny that they are two-faced it is clear that their one face is not facing towards the doctors. All the energies of our negotiators should be directed at the next pay award and the results should be made known six months before the next possible increase, so that full discussion and airing of the doctors' problems can be publicised well before the decision. We should drop all attempts at getting another pay award in this year but should make sure that our demands and if necessary positive action are made in time to influence the pay awards next year. It would appear that our negotiators so time their demands to make the doctors look ridiculous by talking about two pay awards within three months of each other.

It should be obvious that an increase in pay for everyone is only another way of saying a decrease in the value of money for everyone so that the lucky ones with high awards manage to stand still financially and the unlucky ones with low awards or no awards drop further back.

It must be insisted that in any pay award system the present anomalies be eradicated immediately and any payments must be backdated to the last pay increase, the anomalies being: (1) a loss in earnings when a doctor is promoted from senior registrar to consultant; (2) the loss of increments suffered by consultants appointed at the wrong moment; and (3) the temporary (apparently permanent) withholding of statutory pay awards in 1975-6.

Should anyone be so misguided as to think that any hoped-for change in Government will be of help to the doctors let them remember that it was that great business genius $\mathrm{Si}$ Keith Joseph who "reorganised" the Health Service, a benefit from which we and the patients are still suffering and from which we are never likely to recover. The harm that the red-headed vitriolic socialist lady did to us was nothing compared with Sir Keith's efforts.

I do not think that patients can have any hope of "fair play" as long as (1) the Health Service remains a political pawn or (2) one of the larger hospital unions says that the function of the Health Service is to provide employment for its members rather than to provide treatment for its patients.

I cannot say too strongly how dangerous and useless it will be to press for another pay award before April 1978

C R BERKIN

Hull, Humberside

SIR,-With my other colleagues in the BMA I am angry at the way the governments of the day have repeatedly delayed publication of the Review Body reports and have persistently failed to honour them, thereby reducing the medical manpower of this country because doctors have understandably gone elsewhere to find a reasonable standard of living for themselves and their families. I am angry that the NHS, which was in concept a good one, has been short-funded ever since its birth until at the present time it is virtually dying of starvation. I do not, however, applaud the speeches made at Glasgow on the profession's behalf. For one thing-let us be honestthe speakers were not necessarily representing the views of the profession. At the divisional meeting of the BMA in West Sussex, called to send a motion to the Annual Representative Meeting, there were fewer than 20 doctors representing the whole BMA membership in West Sussex, and the chairman commented that it was the best-attended meeting of the year.

We have got to face two facts. Firstly, if phase 3 is allowed to fall there will be a suicidal, unbridled demand for huge wage settlements by many sectors of the community. Secondly, if we are faced by widespread strikes and excessive wage demands this country may see economic and social disorder unparalleled in its history from which democratic society as we have known it may disappear for ever. The only chance of survival is at least the strict adherence to the 12-month rule, however unfair this may be. We must also face the fact that as any confrontation with the Government by the medical profession continues our case will be progressively distorted by the media and we shall lose any sympathy which the general public have for our cause.

I have attended many professional meetings over the past 20 years while in general practice and I have noted that the attitude of doctors has increasingly become one of disregard for public opinion and a belief that our public image must be sacrificed in our fight for our rights. I would remind my colleagues that public opinion means the opinion of our patients, and if our patients feel we are wrong in confronting the Government at this present time, then the doctor-patient relationship is seriously damaged. We have often loftily declared the doctor-patient relationship to be sacred when the Government, through its Department of Health, has threatened to erode it; are we to be so hypocritical as to care naught for it by taking industrial action as the junior doctors have done in recent years? As a family doctor I have witnessed the patient's faith in the hospital doctor decline rapidly in that time, and that particular doctorpatient relationship has been severely damaged The miner can strike for his sectarian interests and go back to the coalface not caring a damn for his public image; we have got to go back to our consulting room or our outpatient clinic with our work made twice as difficult by the barrier that our in dustrial action has put up between the patient and the doctor.

Is there anything we can do as a profession in this critical time for the country and the Health Service? I believe that with everyone demanding a correction of the erosion in their living standards by phases 1 and 2 of the Government's incomes policy. some sector has got to get up and declare its 